\title{
Factors Determining Intention to Use Banking Technology in Indonesian Islamic Microfinance
}

\author{
Kartiko Adi WIBOWO ${ }^{1}$, Abdul Ghafar ISMAIL ${ }^{2}$, Achmad TOHIRIN ${ }^{3}$, Jaka SRIYANA ${ }^{4}$ \\ Received: September 10, 2020 Revised: November 08, 2020 Accepted: November 16, 2020
}

\begin{abstract}
This study aims to determine the perceptions of Islamic Financial Cooperative (BMT) managers in the Indonesian BMT Association on the acceptance of core banking technology. The Technology Acceptance Model (TAM) is used because it has simple theoretical characteristics (parsimony) and is supported by data (verifiability). This study develops the TAM model by integrating new variables -perceptions of maqashid sharia, perceptions of economies of scale, perceptions of market structure, and perceptions of technology procurement costs. These new variables are used to measure intention in using technology and actual usage in BMT operations. This study used PLS-SEM with smartPLS 3. The study was conducted in Central Java in six ex-Residency at 35 BMT with 300 respondents consisting of six levels of position level. The research found that maqashid sharia and market structure directly influenced the intention of BMT managers in using core banking technology. This new finding strengthens a theoretical model regarding the role of maqashid sharia in the acceptance of information technology in BMT. In addition, the perception of economies of scale has no significant effect on intention in using technology or its actual usage. The perception variable of technology procurement costs was found to have no significant effect on intention in using technology.
\end{abstract}

Keywords: Maqasid Sharia, BMT, Islamic Microfinance, Market Structure, Technology Acceptance Model

JEL Classification Code: D03, G02, G21, L63, O14

\section{Introduction}

Information technology is one of the innovations in the modern era that can be used to help various aspects of human life. Huda (2016) states that information technology has various advantages if it can be used properly, such as it can provide added value, help solve problems, and so forth. The use of information systems in a company can provide a competitive advantage and make it able to compete in

${ }^{1}$ First Author and Corresponding Author. PhD Student, Universitas Islam Indonesia, Indonesia [Postal Address: Jl. Taman Sekarjagad 20 RT 01/28, Semarang, 50196, Indonesia] Email: kartiko.aw@gmail.com

${ }^{2}$ Professor of Islamic Financial Economics, Faculty of Economics and Muamalat, Universiti Sains Islam Malaysia, Malaysia.

Email: agibab62@gmail.com

${ }^{3}$ Senior Lecturer, Faculty of Business and Economics, Universitas Islam Indonesia, Indonesia. Email: achmad.tohirin@uii.ac.id ${ }^{4}$ Professor of Economic, Faculty of Business and Economics, Universitas Islam Indonesia, Indonesia. Email: jakasriyana@uii.ac.id

(c) Copyright: The Author(s)

This is an Open Access article distributed under the terms of the Creative Commons Attribution Non-Commercial License (https://creativecommons.org/licenses/by-nc/4.0/) which permits unrestricted non-commercial use, distribution, and reproduction in any medium, provided the original work is properly cited. the marketplace. One example of the use of information technology in financial institutions is the use of fintech. Lien et al. (2020) examines fintech in Vietnam, which is a developing country with a relatively new fintech service. The research results show that fintech services are very important for the banking sector in Vietnam. Research also confirms the factors that influence customer intention to use fintech services. In line with that, the intention to use fintech services (INT) is positively influenced by perceived of usefulness (PU), social impact (SI), customer trust (TRU), and perceived ease-of-use (PEU). Based on the results of this study, bank managers have a basis for improving the quality of fintech services

Thus, the role and function of information systems for companies will become more extensive. Baitul Maal wat Tamwil (BMT) has started implementing information technology system to facilitate transactions with its members. Analysis of the effects of utilization, user expertise, effectiveness of use, and trust in information technology systems on individual performance in the company also needs to be conducted. Information technology has a very big role in the development of BMT in Indonesia, especially in supporting financial transactions for members and providing 
efficiency in the time and costs spent in BMT operational activities.

Many studies have examined the factors that influence the use of technology in the financial industry by using the Technology Acceptance Model (TAM) approach. Lee (2009) found that the factors of convenience, effectiveness, and flexibility play an important role in influencing the use of Internet banking technology. The results of research by Lee, Becker, \& Potluri (2018) in Korea suggest that company needs, social expectations, ease-of-use, and usefulness should be seen as important antecedents explaining corporate behavioral intentions to use social media. This study also found that the ease-of-use and usefulness of the technology acceptance model had a positive directional mediating effect in influencing social media acceptance. This is also supported by Tahar, Riyadh, Sofyani, and Purnomo (2020), that perceived convenience and security perceptions positively affect the intention to use e-filing. Tahar's research was conducted in the city of Semarang, Indonesia, to determine the effectiveness of the use of e-filing provided by the Directorate General of Taxes for civil servants, military and state police.

Likewise, Rahi (2017) confirms that perceived benefits, perceived ease-of-use and attitudes are the main constructs for promoting Internet banking in Pakistan. Several studies on TAM have been developed by adding new variables and integrated with the basic concept of TAM, namely, researching the intention in the use of technology (Hassan et al., 2018; Kumar \& Shenbagaraman, 2017; Al Somali, Gholami, \& Clegg, 2009; Rifai, Asakdiyah, \& Setyawan, 2019; Saji \& Paul, 2018; Bashir \& Madhavaiah, 2015). The disadvantage of the limited research conducted on TAM is that there are no studies that use culture and religion variables as driving factors for intention in the use of technology. Therefore, this study adds a variable that describes a person's perceptions based on their religious understanding, namely, perception of maqashid sharia. This is in line with the research by Phase (2005), Rahmawati (2012) and Muafi (2003), that spiritual motivation plays a major role in one's behavior in selecting technology and performance levels.

\section{Literature Review}

\subsection{Theoretical background}

Previous research on technology adoption in the financial industry sought to understand how different factors influence individual technology adoption behavior. The TAM has gone through three phases of development: adoption, validation, and extension. TAM was developed by Davis (1986) using the basic Theory of Reasoned Action (TRA). TRA was first formulated by Ajzen (1975) who stated that intention determines whether a person does or does not carry out an activity. Sheppard et al. (1988) stated that TRA is widely used as a predictor of behavior in various ways. TRA is used by Davis as his grand theory, although not all TRA components are accommodated in his research. The component of TRA used by Davis is only the 'attitude' component.

\subsubsection{Perceptions of Maqasid Sharia}

There are three gradations in the distribution of maqashid sharia proposed by Syathibi, namely, dharuriyyat (primary), hajjiyyat (secondary), and tahsiniyyat (tertiary). Dharuriyyat includes the maintenance of basic needs in human life. These basic needs include the need for religion (al-din), soul (al-nafs), descent (an-nasl), property (al-maal), and reason $(a l-a q l)$. In the concept of maqashid sharia, the use of technology in financial institutions is a facility (al-wasail) that can be used to protect assets ( $h i d z$ al-maal) by customers.

Rizky (2017) explains that maqashid sharia is the main support in every operational and product development in Islamic banks. Therefore, understanding the importance of maqashid sharia will affect the perceived ease of operation of Islamic financial institutions. Likewise, Firdaus (2018) shows that the perception of maqashid sharia affects patient preferences and perceptions of convenience towards a hospital service. According to Jamal (2016), the understanding of maqashid sharia allows ijtihad to be developed, especially in dealing with various new problems that are not mentioned by the texts. Islamic law will remain dynamic in responding to various social phenomena that are constantly changing and developing. Therefore, this study will develop the perception of BMT employees about maqashid sharia that will affect their intention in the use of technology. This is in line with Nurfalah and Rusdiana (2019) that the ease of technology that was developed allows people to easily access Islamic financial services and products wherever and whenever they need it, according to the concept of maqashid sharia.

\subsubsection{Perceptions of Economies of Scale}

Based on some previous studies, it was found that technology is an important factor for increasing company productivity. Several studies in various business sectors show that technology supports the strengthening of a company's economies of scale. Baumers, Dickens, Tuck, and Hague, (2016) found that the use of technology has an impact on increasing manufacturing production. It was found that, overall, the estimated technology parameters were in line with expectations. Meanwhile, Aivazian (2013) explains that economies of scale are influenced by technological changes as the main determinant, especially in driving productivity growth. It found that technological change explained productivity growth with certainty and even more so in economies of scale. The growth of the economies of scale in 
the company, which is supported by the use of technology, is also found by Mitchell (2002). He found that the role of technology in increasing the rate of plant growth processes greatly, so that companies become more efficient. Bilgihan (2011) found that developing and implementing IT projects can lead to competitive advantages in hotel companies. He showed that IT capabilities and IT competencies can help hotel companies achieve a competitive advantage. Likewise, digitization or utilization of Information Technology in BMT operations is becoming an important tool to achieve performance efficiency.

\subsubsection{Perceptions of Market Structure}

The implementation of the use of technology can be in the form of adding BMT service product facilities, where it is in line with a market structure characterized by monopolism with the same product but has different services offered. In its operations, BMT requires innovation and creativity in the service products offered. The use of technology will encourage the emergence of new services based on accuracy and speed. Thus, technology will make the BMT market even wider in reach. Several studies have confirmed that technology can increase market coverage in the industry.

Hannan and Medowell (2014) show that banks have successfully used ATM (Automatic Teller Machine) to attract customers from competitors. Consequently, the impact of technology adoption on market structure depends on the size of the company adopting new technology. Karaca Mandic et al. (2017) concluded that medical technology diffuses faster in more competitive areas. Furthermore, they found that a more competitive physician market structure could promote faster diffusion by increasing patient access to the latest medical technology. Sutton (2001) found that technological change determines market structure. The findings by Weeds (2012) also support other research that technological changes have changed the creative media industry. The results of his research found that supply-side factors can produce advantages and long-term sustainability, where the use of technology can reduce fixed costs for basic products or decrease market size. Likewise, Elberfeld and Gotz (2002) found that technology is an endogenous variable in the relationship between market size and market structure. Their research yields a simple and fairly intuitive explanation for the phenomenon of industrial shocks. The emerging market is bigger due to the large-scale adoption of technology. They found that technology switching always leads to a reduction in the number of active companies.

\subsubsection{Perception of Technology Procurement Costs}

Flor and Hansen (2013) found that technological advances have an impact on future income, the results of the study show an important long-term effect, that is, the investment threshold increases while the value of options decreases. The application of investing in technology applies to long-term profitability calculations. This is consistent with the results of research by Bessen (2002), that in the manufacturing industry in the United States, technology investment causes productivity to grow around $0.4 \%$ per year faster. Technology procurement costs are included in the long-term investment category. Bessen (2002) also found evidence linking increased productivity with greater investment in IT. Such dramatic changes suggest that companies experience large adoption costs when switching to new technologies so that it will have long-term implications for higher productivity.

Technology procurement is a long-term management decision. Thatcher and Oliver (2001) examined the impact of technology investment on various performance measures. They found that the impact of technology investment increases efficiency. The results show that investment in technology encourages certain efficiency improvements that can maximize profit. More specifically, research shows that investing in technology also reduces a company's fixed overhead costs by not affecting product quality and pricing decisions, even increasing profits and increasing productivity. In addition, research also shows that investment in technology can reduce costs for designing, developing, and manufacturing products which encourages company to improve product quality and charge higher prices.

An efficient company always tries to suppress various investments that absorb large funds. The financial industry will avoid procurement for additional unproductive assets. Every money owned by the company must be able to become productive assets in the form of financing. Therefore, the procurement of fixed assets, both tangible and intangible, will always be considered carefully.

Likewise, the procurement of investment for technology is currently still in the expensive category, so BMT will be careful in carrying out the technology implementation process. Akbar and Noviani (2019) found that the procurement of information technology requires a sufficiently large budget or funds.

\subsubsection{Behavioral Intention}

Behavioral intention has been observed as an indicator of system success (Venkatesh, Morris, Davis, \& Davis, 2003). Intention is defined as the desire to perform behavior. Intention can change over time. Behavioral intention according to Fishbein and Ajzen and many other researchers is a strong predictor of how someone will behave in certain situations. Intention is defined as a condition where someone tends to choose to do or not to do a job. One of the motivating factors in individuals that influence behavior is Intention. Thus, Ajzen (1991) concluded that intention can 
be reflected in how much someone wants to try and the level of motivation to realize certain behaviors.

The results of previous studies indicate that behavioral intention is the best predictor of technology use by system users. Behavioral intention to use is a behavioral tendency to keep using a technology. The level of use of a computer technology in a person can be predicted from the attitude of his attention to the technology, such as the desire to add supporting peripherals, motivation to continue using it, and the desire to motivate other users. The results of the research prove that usefulness and attitude toward using affect a person's tendency to behave.

\subsubsection{Actual System Usage}

The actual system usage is the real situation of a person using a technological system in his life (Davis, 1989). Actual system usage is the same as behavior in TRA. However, it is used in a technological context. This construct is a variable that is directly influenced by intention and perceived ease of use. The actual system usage construct can be measured by 3 (three) indicators, namely real use, actual frequency and user satisfaction (Wibowo, 2006). When technology users have the perception that technology systems are easy to use and will increase their work productivity, they will feel satisfied and will prove the use of technology in real conditions (Tangke, 2004).

\subsection{Hypotheses}

This study develops the TAM variable and builds the following hypotheses:
H1: Perception of Maqashid sharia has a positive effect on intention in using technology.

H2: Perception of market structure has a positive effect on intention in using technology.

H3: Perception of economies of scale has a positive effect on intention in using technology.

H4: Perception of technology procurement costs has a negative effect on intention in using technology.

H5: Intention in using technology has a positive and significant effect on actual system usage.

\section{Methods}

\subsection{Survey Design and Sampling}

This research used a quantitative method to determine the effect and relationship between the independent variable on the dependent variable. To prove the correlation and causal relationship, researchers used quantitative research method of causal research. According to Istijanto (2009), in causal research, researchers will try and aim to determine the variables that influence or cause changes in other variables. Meanwhile, according to Rangkuti (2005), causal research aims to determine the relationship or involvement between these variables. Thus, a quantitative approach is used to verify the effect of the technology acceptance model on the intention to adopt core banking. The questionnaire was developed to measure respondents' observations. The survey was distributed to BMT employees in the Central Java, Indonesia. The sample consisted of 35 BMT and the respondents consisted of six levels of positions at BMT:

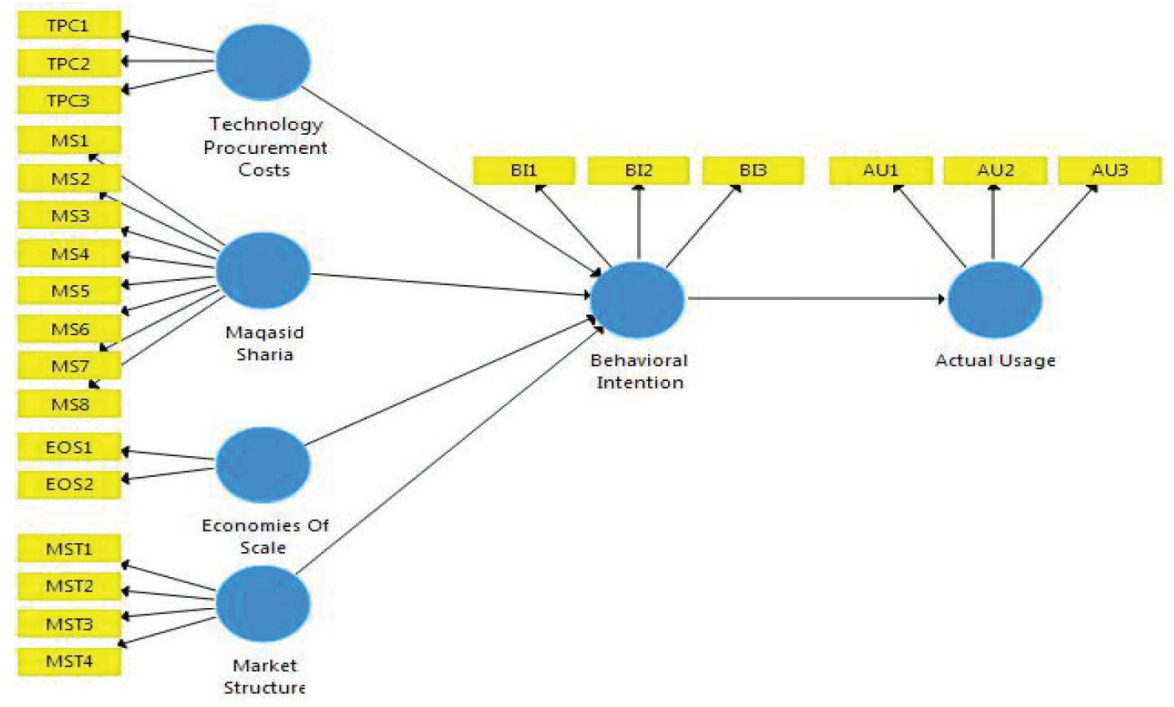

Figure 1: Theoretical Framework 
(a) Manager/Director, (b) Branch Head, (c) Head of Division, (d) Human Resource \& Development, (e) Marketing/ Funding /AO, and (f) Teller/CS (Customer Service).

Data were collected from May to June 2020 from 22 districts in Central Java, Indonesia with cluster random sampling. The cluster random sampling method divides the population into several separate groups known as clusters and a number of randomly selected samples are taken. Cluster random sampling is a sampling technique that is applied when a population is found in groups that appear uniform but internally remain different. Cluster random sampling is a sampling technique that is widely used in geographic statistical groups. This study used a sample size of 300 .

\subsection{Instrument Development}

The survey instrument consists of two parts. The first part asks about demographic characteristics such as region, age, gender, qualifications, while the second part contains six latent constructs, namely, perceptions of maqasid sharia, perceptions of economies of scale, perceptions of market structures, perceptions of technology procurement costs, intention in using technology, and actual system usage. All construction items were adopted from previous research work. The items of maqasid sharia was adapted from Noordin (2019), economies of scale adapted from Priyonggo (2019), market structure adapted from Kidwell and Peterson (1981), technology procurement costs adapted from Akbar and Noviani (2019), intention and actual usage adapted from Davis (1989). All items were given a choice of a 7-point Likert scale (1 for strongly disagrees and 7 for strongly agree).

\subsection{Respondent's Profile}

Demographics of 300 respondents are tabulated in Table 1. There were more males $(61.3 \%)$ than females $(38.7 \%)$. The $25.7 \%$ of respondents were less than 30 years old, $43 \%$ were counted between the ages of 30 to 40 years, $27.7 \%$ for 40 to 50 years and around $3.7 \%$ of respondents were over 50 years old. The data were further analyzed by demographic characteristics such as level of education. Most respondents' level of education was undergraduate degree $(60.3 \%)$, which means that the respondents were educated, for graduate (4.7\%) and Senior High School (20.3\%). The composition of respondents based on position was Teller/CS (42 people), Marketing (41 people), HR\&D (34 people), Head of Division (37 people), Branch Head (111 people), and Manager (35 people). The majority of respondents in this study came at the level of the branch head.

Table 1: Demographic profile of the respondents

\begin{tabular}{|c|c|c|c|}
\hline Characteristics & Items & Frequency & Percentage \\
\hline \multirow[t]{2}{*}{ Gender } & Female & 116 & 38,7 \\
\hline & Male & 184 & 61,3 \\
\hline \multirow[t]{4}{*}{ Age } & 19 - 30 years old & 77 & 25,7 \\
\hline & $>30-40$ years old & 129 & 43 \\
\hline & $>40-50$ years old & 83 & 27,7 \\
\hline & $>50$ years old & 11 & 3,7 \\
\hline \multirow[t]{4}{*}{ Education level } & Senior High School & 61 & 20,3 \\
\hline & Diploma & 44 & 14,7 \\
\hline & \begin{tabular}{|l|} 
Undergraduate \\
\end{tabular} & 181 & 60,3 \\
\hline & Graduate & 14 & 4,7 \\
\hline \multirow[t]{6}{*}{ Position } & Teller / CS & 42 & 14 \\
\hline & Marketing & 41 & 13,7 \\
\hline & HR\&D & 34 & 11,3 \\
\hline & Head of Division & 37 & 12,3 \\
\hline & Branch Head & 111 & 37 \\
\hline & Manager/director & 35 & 11,7 \\
\hline \multirow[t]{5}{*}{ Tenure } & $<5$ years & 49 & 16,3 \\
\hline & $>5-10$ years & 107 & 35,7 \\
\hline & $>10-15$ years & 76 & 25,3 \\
\hline & $>15-20$ years & 37 & 12,3 \\
\hline & $>20$ years & 31 & 10,3 \\
\hline
\end{tabular}




\section{Data Analysis Technique}

The model was analyzed by using the Partial Least Square (PLS) analysis technique with SmartPLS 3.2.8 (Starstedt, 2017). The analytical procedure was carried out in two stages, the researcher tested the measurement model (validity and reliability) and the structural model (Hypothesis testing) recommended by Hair Jr. et al. (2014).

\subsection{Measurement Model}

Research must begin by evaluating the latent construct measurement model for its validity and reliability by going through a process of confirmatory factor analysis (CFA). Because this study is quantitative, it usually used Cronbach $(\alpha)$ to ensure reliability. However, Composite Reliability (CR) is recommended more (Henseler et al., 2009). Two types of validity used are convergent and discriminative validity.

\subsection{Convergent Validity}

The convergent validity of the measurement model is usually ascertained by examining the loading factor, extracted mean variance, and reliability (Hair et al., 2010). Figure 2 illustrates the result where the loading factor value is supported by Chin (1998), the recommended threshold level is 0.6 . All values above 0.6 indicate convergent validity. Likewise, all composite reliability values were above 0.7 (Sarstedt, 2019).
Convergent validity was confirmed by the Average Variance Extracted (AVE) estimation with the value recommended by Fornell and Larcker (1981), which is greater than 0.5. Average Variance Extracted which reflects the total variance in the indicator is accounted for the latent construct.

Furthermore, this study conducted measurements by assessing composite reliable. Table 2 illustrates the degree of composite reliability (CR) where the value must exceed 0.7 recommended by Hair et al. (2010). The result of calculating all $C R$ values above 0.7 indicates that all constructs are reliable.

\subsection{Discriminant Validity}

Discriminant validity is to compare each square root of AVE to the correlation value between constructs. The calculation is carried out by taking into account the value in the test of Fornell-Larcker Criterion (1981) and the crossloading value. The variable is said to be fit if the square root value of AVE is higher than the correlation between constructs. Table 3 shows that the square root of the AVE as shown in the bolded value is greater than the corresponding row and column value, it means the measure is discriminant.

The next step is to examine the cross-loading value, which is to evaluate the correlation value of variables with indicators that are greater than the correlation among other constructs (Hair Jr. et al., 2016). Table 4 illustrates that the correlation value of each variable on the indicator is above 0.7 and all of them are greater than the correlation among other constructs. Based on the cross-loading test above, it can be concluded that the constructs built in this research model are valid.

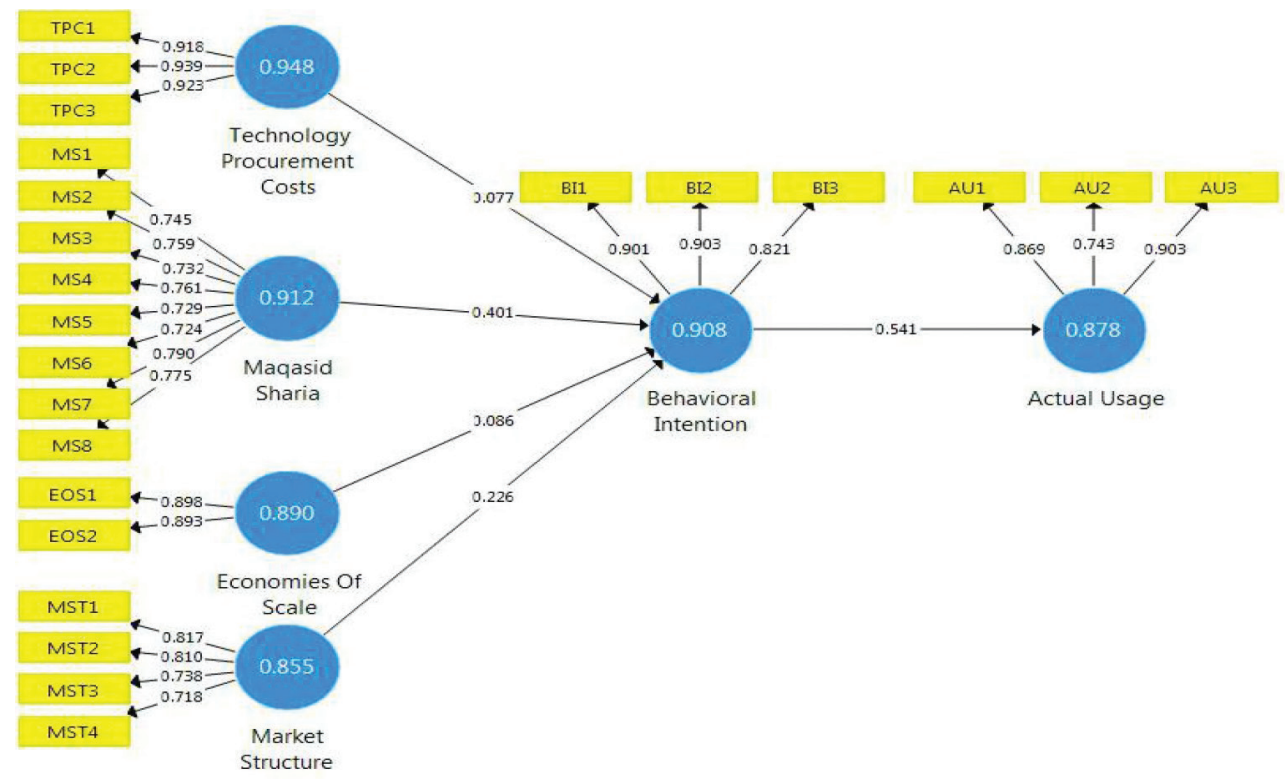

Figure 2: Measurement Model 
Table 2: Results of Measurement Model

\begin{tabular}{|c|c|c|c|c|}
\hline Constructs & Loading & $(\alpha)$ & CR & AVE \\
\hline Maqasid Sharia & MS & 0,890 & 0,912 & 0,566 \\
\hline $\begin{array}{l}\text { The use of technology has broadened the understanding (literacy) of BMT } \\
\text { as a sharia micro institution. }\end{array}$ & 0,745 & & & \\
\hline $\begin{array}{l}\text { The use of technology has made the poverty alleviation program carried out by BMT } \\
\text { wider }\end{array}$ & 0,759 & & & \\
\hline $\begin{array}{l}\text { The use of technology expands job opportunities by opening businesses financed } \\
\text { by BMT. }\end{array}$ & 0,732 & & & \\
\hline $\begin{array}{l}\text { The use of technology is able to provide data that makes research easier for BMT } \\
\text { development. }\end{array}$ & 0,761 & & & \\
\hline The use of technology makes profit sharing more transparent by BMT. & 0,728 & & & \\
\hline $\begin{array}{l}\text { The use of technology facilitates process analysis when a financing restructuring is } \\
\text { carried out. }\end{array}$ & 0,724 & & & \\
\hline The use of technology increases the productivity of BMTs. & 0,789 & & & \\
\hline \multicolumn{5}{|l|}{ The use of technology improves the quality of the BMT management system. } \\
\hline Economies of Scale & EOS & 0,840 & 0,886 & 0,610 \\
\hline $\begin{array}{l}\text { The use of technology encourages a better level of member trust so that it can } \\
\text { increase the amount of funds deposited in BMT. }\end{array}$ & 0,896 & & & \\
\hline The use of technology makes BMT more efficient. & 0,894 & & & \\
\hline Market Structure & MST & 0,775 & 0,855 & 0,596 \\
\hline $\begin{array}{l}\text { The use of technology increases the market share of BMT among the same financial } \\
\text { business actors in the BMT working area (by comparing the market share to other } \\
\text { BMTs). }\end{array}$ & 0,817 & & & \\
\hline $\begin{array}{l}\text { The use of technology provides data accuracy so that it will be easier to } \\
\text { prepare business development which can ensure the long-term business } \\
\text { continuity of BMT. }\end{array}$ & 0,810 & & & \\
\hline $\begin{array}{l}\text { The use of technology will make BMT more efficient so that it can reduce the margin } \\
\text { in Murabaha contract, thereby increasing the competitiveness of BMTs. }\end{array}$ & 0,738 & & & \\
\hline $\begin{array}{l}\text { The use of technology by BMTs will add to service product facilities in business } \\
\text { competition so as to inhibit the entry of competitors to the BMT work area. }\end{array}$ & 0,718 & & & \\
\hline Technology Procurement Costs & PCT & 0,919 & 0,948 & 0,858 \\
\hline The price for hardware procurement is not expensive. & 0,918 & & & \\
\hline The price for purchasing software is not expensive. & 0,939 & & & \\
\hline Internet usage fees are not expensive. & 0,923 & & & \\
\hline Intention in using technology & $\mathrm{BI}$ & 0,847 & 0,908 & 0,767 \\
\hline I still want to use the technology used by BMT in the future. & 0,901 & & & \\
\hline I will continue to use the technology used by BMT intensively. & 0,903 & & & \\
\hline I will invite other BMT friends to use the technology used by BMT. & 0,821 & & & \\
\hline Actual system usage & $\mathrm{AU}$ & 0,794 & 0,878 & 0,707 \\
\hline I use technology at BMT every day. & 0,869 & & & \\
\hline I use technology at BMT 8 hours a day. & 0,744 & & & \\
\hline I use technology at BMT continuously. & 0,902 & & & \\
\hline
\end{tabular}


Table 3: Discriminant validity of Measurement Model

\begin{tabular}{|l|c|c|c|c|c|c|}
\hline & $\begin{array}{c}\text { Technology } \\
\text { Procurement } \\
\text { Costs }\end{array}$ & $\begin{array}{c}\text { Maqashid } \\
\text { Sharia }\end{array}$ & $\begin{array}{c}\text { Intention } \\
\text { in Using } \\
\text { technology }\end{array}$ & $\begin{array}{c}\text { Actual } \\
\text { System } \\
\text { Usage }\end{array}$ & $\begin{array}{c}\text { Economies } \\
\text { of Scale }\end{array}$ & $\begin{array}{c}\text { Market } \\
\text { Structure }\end{array}$ \\
\hline Technology Procurement Costs & $0,927^{*}$ & & & & & \\
\hline Maqashid Sharia & 0,403 & $0,752^{*}$ & & & & \\
\hline Intention in Using Technology & 0,374 & 0,664 & $0,876^{*}$ & & & \\
\hline Actual System Usage & 0,166 & 0,497 & 0,541 & $0,841^{*}$ & & \\
\hline Economies of Scale & 0,350 & 0,730 & 0,553 & 0,404 & $0,895^{*}$ & \\
\hline Market Structure & 0,464 & 0,747 & 0,618 & 0,385 & 0,650 & $0,772^{*}$ \\
\hline
\end{tabular}

Note: Bolded values indicate the square root of AVE of each construct.

Table 4: Loading and Cross Loadings

\begin{tabular}{|c|c|c|c|c|c|c|}
\hline Items & $\begin{array}{c}\text { Technology } \\
\text { Procurement Costs }\end{array}$ & $\begin{array}{l}\text { Maqashid } \\
\text { Sharia }\end{array}$ & $\begin{array}{c}\text { Intention } \\
\text { in using } \\
\text { technology }\end{array}$ & $\begin{array}{c}\text { Actual } \\
\text { System } \\
\text { Usage }\end{array}$ & $\begin{array}{l}\text { Economies } \\
\text { of Scale }\end{array}$ & $\begin{array}{c}\text { Market } \\
\text { Structure }\end{array}$ \\
\hline MS1 & 0,306 & $0,745^{*}$ & 0,521 & 0,398 & 0,550 & 0,578 \\
\hline MS2 & 0,389 & $0,759^{*}$ & 0,449 & 0,289 & 0,452 & 0,615 \\
\hline MS3 & 0,371 & $0,732^{*}$ & 0,447 & 0,305 & 0,465 & 0,556 \\
\hline MS4 & 0,237 & $0,761^{*}$ & 0,533 & 0,495 & 0,547 & 0,478 \\
\hline MS5 & 0,260 & $0,728^{*}$ & 0,473 & 0,336 & 0,524 & 0,524 \\
\hline MS6 & 0,235 & $0,724^{*}$ & 0,480 & 0,342 & 0,470 & 0,531 \\
\hline MS7 & 0,341 & $0,789^{*}$ & 0,568 & 0,392 & 0,665 & 0,608 \\
\hline MS8 & 0,299 & $0,775^{*}$ & 0,505 & 0,409 & 0,686 & 0,608 \\
\hline EOS1 & 0,307 & 0,671 & 0,500 & 0,419 & $0,896^{*}$ & 0,535 \\
\hline EOS2 & 0,321 & 0,637 & 0,490 & 0,303 & $0,894^{*}$ & 0,628 \\
\hline MST1 & 0,327 & 0,599 & 0,501 & 0,298 & 0,543 & $0,817^{*}$ \\
\hline MST2 & 0,336 & 0,660 & 0,563 & 0,395 & 0,592 & $0,810^{*}$ \\
\hline MST3 & 0,401 & 0,545 & 0,415 & 0,284 & 0,437 & $0,738^{*}$ \\
\hline MST4 & 0,393 & 0,480 & 0,402 & 0,182 & 0,403 & $0,718^{*}$ \\
\hline $\begin{array}{l}\text { TPC1 } \\
2 \\
\end{array}$ & $0,918^{*}$ & 0,359 & 0,299 & 0,120 & 0,299 & 0,442 \\
\hline TPC2 & $0,939^{*}$ & 0,358 & 0,294 & 0,120 & 0,298 & 0,432 \\
\hline TPC3 & $0,923^{*}$ & 0,395 & 0,417 & 0,202 & 0,361 & 0,419 \\
\hline $\mathrm{Bl} 1$ & 0,293 & 0,582 & $0,901^{*}$ & 0,476 & 0,509 & 0,529 \\
\hline $\mathrm{BI} 2$ & 0,358 & 0,627 & $0,903^{*}$ & 0,533 & 0,506 & 0,572 \\
\hline $\mathrm{BI} 3$ & 0,333 & 0,531 & $0,821^{*}$ & 0,403 & 0,434 & 0,519 \\
\hline AU1 & 0,142 & 0,451 & 0,487 & $0,869^{*}$ & 0,362 & 0,295 \\
\hline AU2 & 0,126 & 0,303 & 0,336 & $0,744^{*}$ & 0,267 & 0,258 \\
\hline AU3 & 0,151 & 0,475 & 0,515 & $0,902^{*}$ & 0,376 & 0,404 \\
\hline
\end{tabular}




\subsubsection{Heterotrait-Monotrait Ratio (HTMT)}

Another approach to assessing discriminant validity suggested by Henseler et al. (2015) is by using multi-trait and multi-method matrices, namely, Heterotrait-Monotrait Ratio (HTMT). The recommended HTMT value of smartPLS should be less than 0.9 (Gold \& Malhotta, 2001). From Table 5, it can be seen that all HTMT values are less than 0.9 , it means, the model is valid.

\subsection{Structural Model Evaluation}

Structural equation modeling (SEM) was conducted to assess the strength of the proposed model for this study. To assess the lateral collinearity test of the structural model (VIF), R2 value, and t-value, it was adopted from Hair Jr. et al. (2016). The proposed hypothesis was tested by running a bootstrap procedure with resample 5000, as suggested by Hair Jr. et al. (2014).

\subsection{Collinearity Statistics}

In the first step of structural equation modeling, lateral collinearity is assessed by the VIF collinearity statistic. Collinearity statistics is known by looking at the value of the Variance Inflation Factor (VIF) and free from multicollinearity phenomena, the VIF value must be below 5 . This collinearity occurs when the two variables which are hypothesized to have a causal relationship measure the same construct. This type of collinearity is assessed by the VIF value, If the VIF value is 3.3 or higher, it indicates the potential for collinearity (Diamantopoulos \& Siguaw, 2006). Table 6 shows the Inner VIF value is below 5 , which means the model is fit (Diamantopoulos \& Siguaw, 2006).

As described in Table 6, the VIF values are less than 5 and 3.3 , indicating that there is no lateral multi-collinearity in this study based on the statement of Hair Jr. et al. (2014).

\subsection{Hypotheses Testing}

The hypothesis development in this study was tested by running a bootstrap procedure with resample 5000, as suggested by Hair Jr. et al. (2014). Table 7 describes the path coefficient of each construct with its level of significance.

The results showed that the three hypotheses had a significant relationship with each endogenous variable. H2 is not significant in the relationship between economies of scale and technology procurement cost. Table 7 illustrates that the relationship between maqashid sharia and intention in using technology as stated by H1: (t-statistic $=5.346>$ 1.96 and $\mathrm{p}<0.05)$. Furthermore, the relationship between perceived market structure and intention in using technology is supported as stated by H3: (t-statistic $=3.122>1.96$ and $\mathrm{p}<0.05)$. H5 shows that intention in using technology is positively related to actual system usage ( $\mathrm{t}$-statistic $=$ $10.656>1.96$ and $\mathrm{p}<0.05$.

Table 6: Results of Collinearity Statistics

\begin{tabular}{|l|c|c|}
\hline & $\begin{array}{c}\text { Intention } \\
\text { in Using } \\
\text { Technology }\end{array}$ & $\begin{array}{c}\text { Actual } \\
\text { System } \\
\text { Usage }\end{array}$ \\
\hline $\begin{array}{l}\text { Technology Procurement } \\
\text { Costs }\end{array}$ & 1,288 & \\
\hline Maqashid Sharia & 2,971 & \\
\hline $\begin{array}{l}\text { Intention in Using } \\
\text { Technology }\end{array}$ & & 1,000 \\
\hline Actual System Usage & 2,265 & - \\
\hline Economies of Scale & 2,553 & \\
\hline Market Structure & & \\
\hline
\end{tabular}

Table 5: Heterotrait-Monotrait Ratio (HTMT)

\begin{tabular}{|l|c|c|c|c|c|}
\hline & $\begin{array}{c}\text { Technology } \\
\text { Procurement } \\
\text { Costs }\end{array}$ & $\begin{array}{c}\text { Maqashid } \\
\text { Sharia }\end{array}$ & $\begin{array}{c}\text { Intention } \\
\text { in using } \\
\text { technology }\end{array}$ & $\begin{array}{c}\text { Actual System } \\
\text { Usage }\end{array}$ & $\begin{array}{c}\text { Economies } \\
\text { of Scale }\end{array}$ \\
\hline Technology Procurement Costs & ------ & & & \\
\hline Maqashid Sharia & 0,444 & & & \\
\hline Intention in Using Technology & 0,411 & 0,758 & & \\
\hline Actual System Usage & 0,187 & 0,574 & 0,643 & & \\
\hline Economies of Scale & 0,414 & 0,885 & 0,691 & 0,515 & 0,471 \\
\hline Market Structure & 0,560 & 0,891 & 0,751 & 0,837 \\
\hline
\end{tabular}

Note: Heterotrait-Monotrait Ratio (HTMT) discriminant at (HTMT <0.9). 
Table 7: Results of Structural Model Analysis (Hypothesis Testing)

\begin{tabular}{|l|l|c|c|c|c|c|c|}
\hline$\#$ & \multicolumn{1}{|c|}{ Constructs } & $\begin{array}{c}\text { Original } \\
\text { Sample } \\
(\mathbf{O})\end{array}$ & $\begin{array}{c}\text { Sample } \\
\text { Mean } \\
(\mathbf{M})\end{array}$ & $\begin{array}{c}\text { Standard } \\
\text { Deviation } \\
(\mathbf{S T D E V})\end{array}$ & $\begin{array}{c}\text { T Statistics } \\
(\text { (IO/STDEV|) }\end{array}$ & P Values & Results \\
\hline H1 & Maqasid sharia $\rightarrow$ Intention & 0,401 & 0,400 & 0,075 & $5,346^{*}$ & $0,000^{*}$ & Supported \\
\hline H2 & Economies of Scale $\rightarrow$ Intention & 0,086 & 0,088 & 0,073 & 1,181 & 0,238 & Unsupported \\
\hline H3 & Market Structure $\rightarrow$ Intention & 0,226 & 0,231 & 0,072 & $3,122^{*}$ & $0,002^{*}$ & Supported \\
\hline H4 & $\begin{array}{l}\text { Technology Procurement Costs } \rightarrow \\
\text { Intention }\end{array}$ & 0,077 & 0,076 & 0,041 & 1,899 & 0,058 & Unsupported \\
\hline H5 & Intention $\rightarrow$ Actual system Usage & 0,541 & 0,547 & 0,051 & $10,656^{*}$ & $0,000^{*}$ & Supported \\
\hline
\end{tabular}

Note: Significance level where, ${ }^{*} p<0.05$.

Table 8: Evaluating Effect Size

\begin{tabular}{|l|l|c|c|c|c|}
\hline Path & Constructs & $\mathbf{R}^{\mathbf{2}}$ & $\mathbf{Q}^{\mathbf{2}}$ & $\mathbf{f}^{\mathbf{2}}$ & Decision \\
\hline & $\begin{array}{l}\text { Behavioral } \\
\text { Intention }\end{array}$ & 0,483 & 0,345 & & \\
\hline & $\begin{array}{l}\text { Actual } \\
\text { Usage }\end{array}$ & 0,293 & 0,192 & & \\
\hline $\mathrm{H} 1$ & $\mathrm{MS} \rightarrow \mathrm{BI}$ & & & 0,105 & Medium \\
\hline $\mathrm{H} 2$ & $\mathrm{EOS} \rightarrow \mathrm{BI}$ & & & 0,006 & Small \\
\hline $\mathrm{H} 3$ & $\mathrm{MST} \rightarrow \mathrm{BI}$ & & & 0,039 & Medium \\
\hline $\mathrm{H} 4$ & $\mathrm{TPC} \rightarrow \mathrm{BI}$ & & & 0,009 & Small \\
\hline $\mathrm{H} 5$ & $\mathrm{BI} \rightarrow \mathrm{AU}$ & & & 0,414 & Large \\
\hline
\end{tabular}

Note: $f^{2} 0.02$, small; 0.15 , medium; 0.35 , large.

\subsection{Evaluating Effect Size}

$\mathrm{R}^{2}$ values for interest in using technology and actual system usage are 0.483 and 0.293 , both are accepted based on the suggestion of Cohen (1988). We also assessed the effect size $\left(\mathrm{f}^{2}\right)$. As stated by Cohen (1988), the $\mathrm{P}$ value can indicate an influence but does not reveal the magnitude of the influence. In Table 8, the effect size ( $\left({ }^{2}\right)$ can be seen where $\mathrm{H} 5$ describes a large effect size, while $\mathrm{H} 1$ and $\mathrm{H} 3$ have a medium effect size. $\mathrm{H} 2$ and $\mathrm{H} 4$ present small effect sizes as suggested by Cohen (1988). Furthermore, the relevance of the model predictions was assessed by using a blindfolding procedure. The blindfolding procedure should only be applied to endogenous constructs that have reflective measurements (Hair Jr et al., 2016). If the $\mathrm{Q}^{2}$ value is greater than 0 , it indicates that the model has predictive relevance for certain endogenous constructs (Cohen, 1988; Hair Jr. et al., 2016). Table 8 shows that the value of $Q^{2}$ is greater than 0 , meaning that the proposed model has significant predictive relevance.

\section{Discussion and Conclusion}

This study investigates the relationship between the proposed variables and examines their effect on the intention of BMT employees to use core banking. The character of BMT as a microfinance institution has similarities with financial institutions in general. Furst et al. (2002) stated that the profitability of financial institutions that use Internet banking is higher than non-Internet banking users. Furthermore, Internet banking creates new marketing opportunities and increases customer loyalty (Rahi, 2016). Thus, the use of technology on BMT will have the same impact as the impact obtained by other financial institutions. BMTs in Indonesia need to know the factors that influence the adoption of core banking. The model built on the research guides finding the core factors of technology acceptance from BMT employees. Intention in core banking is measured by the perception of maqasid sharia, perceptions of economies of scale, perceptions of market structures and perceptions of costs of technology procurement. This concluded that maqashid sharia and market structure have a positive and significant relationship with the behavior intention in using core banking technology in BMTs. Meanwhile, economies of scale and technology procurement costs do not have a significant influence on the intention of BMT managers to use core banking technology.

\section{References}

Aivazian, V. A., Callen, J. L., Chan, M. W. L., \& Mountain, D. C. (2013). Economies of Scale Versus Technological Change in the Natural Gas Transmission Industry. Journal The Review of Economics and Statistics, 69(3), 556-561.

Ajzen, I. (1991). The Theory of Planned Behavior. Organizational Behavior And Human Decision Processes, 53(1), 51-58. 
Al-Somali, S. A., Gholami, R., \& Clegg, B. (2009). An investigation into the acceptance of online banking in Saudi Arabia. Technovation, 29(2), 130-141. https://doi.org/10.1016/j. technovation.2008.07.004

Bashir, I., \& Madhavaiah, C. (2015). Trust, Social Influence, Self-Efficacy, Perceived Risk, and Internet Banking Acceptance: An Extension of Technology Acceptance Model in Indian Context. Metamorphosis: A Journal of Management Research, 14(1), 25-38. https://doi. org/10.1177/0972622520150105

Baumers, M., Dickens, P., Tuck, C., \& Hague, R. (2016). The cost of additive manufacturing: Machine productivity, economies of scale, and technology-push. Technological Forecasting and Social Change, 102, 193-201. https://doi.org/10.1016/j. techfore.2015.02.015

Bessen, J. (2002). Technology adoption costs and productivity growth: The transition to information technology. Journal of Economic Literature, 5(2), 443-469. https://doi.org/10.1006/ redy.2001.0152

Bilgihan, A., Okumus, F., Nusair, K. K., \& Kwun, D. J. W. (2011). Information technology applications and competitive advantage in hotel companies. Journal of Hospitality and Tourism Technology, 2(2), 139-153. https://doi. org/10.1108/17579881111154245

Cohen, J. (1988). Statistical power analysis for the behavioral sciences. Hillsdale, NJ: Lawrence Earlbaum Associates

Chin, W. (1998). Commentary: Issues and Opinion on Structural Equation Modeling. MIS Quarterly, 22(1), Vii-Xvi. Retrieved July 9, 2020, from http://www.jstor.org/stable/249674

Davis, F. D. (1989). Perceived usefulness, perceived ease of use, and user acceptance of information technology. MIS Quarterly: Management Information Systems, 13(3), 319-339. https://doi. org/10.2307/249008

Diamantopoulos, A., \& Siguaw, J. A. (2006). Formative Versus Reflective Indicators in Organizational Measure Development : A Comparison and Empirical Illustration. British Journal of Management, 17, 263-282. https://doi.org/10.1111/j.14678551.2006.00500.x

Elberfeld, W., \& Götz, G. (2002). Market size, technology choice, and market structure. German Economic Review, 3(1), 25-41. https://doi.org/10.1111/1468-0475.00050

Fishbein, M., \& Ajzen, I. (1975). Belief, Attitude, Intention, and Behavior: An Introduction to Theory and Research. University of Massachusetts Amherst

Flor, C. R., \& Hansen, S. L. (2013). Technological advances and the decision to invest. Ann Finance, 9(3), 383-420. https://doi. org/10.1007/s10436-012-0191-4

Fornell, C., \& Larcker, D. F. (1981). Structural equation models with unobservable variables and measurement error: Algebra and statistics. Journal of Marketing Research, 382-388.

Furst, K., Lang, W. W., \& Nolle, D. E. (2002). Internet banking. Journal of Financial Services Research, 22(1-2), 95-117.
Gold, A. H., \& Arvind Malhotra, A. H. S. (2001). Knowledge management: An organizational capabilities perspective. Journal of Management Information Systems, 18(1), 185-214.

Hair, Jr, J. F., Hult, G. T. M., Ringle, C., \& Sarstedt, M. (2016). A primer on partial least squares structural equation modeling (PLS-SEM). Thousand Oaks, CA: Sage Publications.

Hair Jr, J. F., Black, W. C., Babin, B. J., Anderson, R. E., \& Tatham, R. L. (2010). SEM: An introduction. Multivariate data analysis: A global perspective, 5(6), 629-686.

Hair, Jr, J., Sarstedt, M., Hopkins, L., \& G. Kuppelwieser, V. (2014). Partial least squares structural equation modeling (PLS-SEM) An emerging tool in business research. European Business Review, 26(2), 106-121.

Hannan, T. H., \& Mcdowell, J. M. (2014). The Impact of Technology Adoption on Market Structure. The Review of Economics Economics and Statistics, 72(1), 164-168.

Henseler, J., Ringle, C. M., \& Sarstedt, M. (2015). A new criterion for assessing discriminant validity in variance-based structural equation modeling. Academy of Marketing Science. Journal, 43(1), 115.

Henseler, J., Ringle, C. M., \& Sinkovics, R. R. (2009). The use of partial least squares path modeling in international marketing. Advances in International Marketing, 20(1), 277-319.

Huda, M. Q., Hidayah, N. A., \& Putra, S. J. (2016). A study of social technology use in State Islamic University (UIN) Syarif Hidayatullah Jakarta. In: Cyber and IT Service Management, International Conference (pp. 1-6).

Hudaefi, F. A., \& Noordin, K. (2019). Harmonizing and constructing an integrated maqāșid al- Sharī'ah index for measuring the performance of Islamic banks. ISRA International Journal of Islamic Finance. https://doi.org/10.1108/ijif-01-2018-0003

Istijanto, (2009). Practical Applications of Marketing Research. Jakarta, Indonesia: Gramedia Pustaka Utama.

Kumar, G., \& Shenbagaraman, V. M. (2017). The customers' perception of mobile banking adoption in Chennai City. An empirical assessment of an extended technology acceptance model. International Journal of Business Information Systems, 26(1), 46-65. https://doi.org/10.1504/IJBIS.2017.086056

Lee, J. W., Becker, K., \& Potluri, R. M. (2018). Antecedents of Corporate Adoption of Social Media and the Role of the Technology Acceptance Model in the Path. Journal of Asian Finance, Economics and Business, 3(2), 67-76. https://doi. org/10.13106/jafeb.2016.vol3.no2.67.

Lien, N. T. K., Doan, T. R. T., \& Bui, T. N. (2020). Fintech and banking: Evidence from Vietnam. Journal of Asian Finance, Economics and Business, 7(9), 419-426. https://doi. org/10.13106/jafeb.2020.vol7.no9.419

Malhotra, Y., \& Galletta, D. F. (1999). Extending the Technology Acceptance Model to account for social influence: Theoretical bases and empirical validation. In: Proceedings of the Hawaii International Conference on System Sciences. https://doi. org/10.1109/hicss.1999.772658 
Mitchell, M. F. (2002). Technological change and the scale of production. Journal of Economic Literature, 5(2), 477-488. https://doi.org/10.1006/redy.2002.0171

Muafi, M. (2003). The Effect of Employee Spiritual Motivation on Religious Performance: An Empirical Study in the Rungkut Industrial Area, Surabaya. Journal of Siasat Bisnis, 1(8), 1.

Rahi, S. (2017). Predicting customer's intentions to use internet banking: the role of technology acceptance model (TAM) in e-banking. Management Science Letters, 7, 513-524. https:// doi.org/10.5267/j.msl.2017.8.004

Rahmawati, A. (2012). Behavior Model of Internet Banking Acceptance in Islamic Banks: The Role of Spiritual Motivation. Sunan Ampel Islamic University. Retrieved December 18, 2019 from http://digilib.uinsby.ac.id/id/eprint/7660

Rangkuti, F. (2005). SWOT Analysis of Business Concept Mechanism Techniques. Jakarta, Indonesia: Gramedia Pustaka Utama.

Rifai, S., Asakdiyah, S., \& Setyawan, R. R. (2019). Analysis of Acceptance of Banking System Based on Technology Readiness and Acceptance Model in Sharia Rural Bank of Bangun Drajat Warga at Yogyakarta Indonesia. Perisai : Islamic Banking and Finance Journal, 3(1), 57. https://doi.org/10.21070/perisai. v3i1.2102

Rizky, S. (2017). Islamic Maqashid Application in the Field of Islamic Banking. Jurnal Ekonomi dan Keuangan Syariah, 1(2), 231-245. https://doi.org/10.1017/CBO9781107415324.004

Saji, T. G., \& Paul, D. (2018). Behavioral Intention to the Use of Mobile Banking in Kerala: An Application of Extended Classical Technology Acceptance Model. Metamorphosis: A Journal of Management Research, 17(2), 111-119. https:// doi.org/10.1177/0972622518792802

Sheppard, B. H., Hartwick, J., \& Warshaw, P. R. (1988). The Theory of Reasoned Action: A Meta-Analysis of Past Research with
Recommendations for Modifications and Future Research. Journal of Consumer Research, 15(3), 325. https://doi. org/10.1086/209170

Sarstedt, M., \& Cheah, J. H. (2019). Partial least squares structural equation modeling using SmartPLS: a software review. Journal of Marketing Analytics, 7(3), 196-202. https://doi.org/10.1057/ s41270-019-00058-3

Sarstedt, M., Ringle, C. M., \& Hair, J. F. (2017). Partial Least Squares Structural Equation Modeling. https://doi. org/10.1007/978-3-319-05542-8_15-1

Suseno P. (2008). Analysis of efficiency and economies of scale in the Islamic banking industry in Indonesia. Journal of Islamic and Economics, 2 (1), 35-55

Sutton, J, (2001). Technology and Market Structure: Theory and History. Cambride, MA: MIT Press

Tahar, A., Riyadh, H. A., Sofyani, H., \& Purnomo, W. E. (2020). Perceived ease of use, perceived usefulness, perceived security and intention to use e-filing: The role of technology readiness. Journal of Asian Finance, Economics and Business, 7(9), 537-547. https://doi.org/10.13106/jafeb.2020.vol7. no9.537

Tangke, N. (2004). Acceptance Analysis of the Application of Computer Assisted Audit Techniques Using the Technology Acceptance Model (TAM) at the Indonesian Financial Audit Board. Jurnal Akuntansi dan Keuangan, 6(1), Mei: 10-28.

Venkatesh, V., Morris, M. G., Davis, G. B., \& Davis, F. D. (2003). User acceptance of information technology: toward a unified view. MIS Quarterly, 27, 425-478.

Weeds, H. (2012). Superstars and the long tail: The impact of technology on the market structure in media industries. Information Economics and Policy, 24(1), 60-68. https://doi. org/10.1016/j.infoecopol.2012.01.008 